\title{
The Amount and Usefulness of Written Corrective Feedback Across Different Educational Contexts and Levels
}

\section{Maria-Lourdes Lira-Gonzales $\mathcal{E}$ Hossein Nassaji}

This study examined and compared different written corrective feedback techniques used by English as a second language (ESL) teachers in three different educational contexts and levels (primary, secondary, and college) in Quebec, Canada. In particular, it examined whether there were any differences in the types of errors made, the kind and degree of feedback provided, as well as the students' ability to incorporate the feedback while revising their texts. Data were collected at the three aforementioned contexts from six ESL teachers in their intact classes when they corrected their students' $(N=128)$ written essays (drafts and revisions). Results revealed an important difference across the three levels in terms of students' errors, teachers' feedback, and students' revisions. They showed that (a) while grammatical errors were made more frequently by primary students, lexical errors were made more frequently by college students; (b) primary and secondary students received more direct than indirect feedback, while college students received more indirect feedback; (c) the secondary and college students were more successful in incorporating the feedback into their revisions than primary students.

La présente étude a examiné et comparé plusieurs techniques de rétroactions correctives écrites utilisées par des enseignants d'anglais langue seconde (ALS) dans trois contextes et niveaux d'éducation différents (primaire, secondaire et collégial) au Québec, au Canada. En particulier, elle a examiné s'il existait des différences dans les types d'erreurs qui étaient faites, quelle sorte et quel niveau de rétroaction étaient fournis ainsi que la capacité des élèves à intégrer la rétroaction lorsqu'ils révisaient leurs textes. On a recueilli des données dans les trois contextes susmentionnés auprès de six enseignants d'ALS dans leurs classes intactes lorsqu'ils corrigeaient les rédactions (brouillons et révisions) de leurs élèves $(N=128)$. Les résultats ont révélé une différence importante dans les trois niveaux en ce qui concerne les erreurs des élèves, la rétroaction des enseignants et les révisions des élèves. Les résultats ont montré que (a), alors que les élèves de primaire faisaient plus d'erreurs grammaticales, les élèves de collège faisaient plus d'erreurs lexicales; (b) les élèves de primaire et de secondaire recevaient plus de rétroaction directe qu'indirecte, alors que les élèves de collège recevaient plus de rétroaction indirecte; (c) les élèves de secondaire et de collège réussissaient mieux à incorporer la rétroaction dans leurs révisions que les élèves de primaire. 
Key words: Written corrective feedback, written revision, written error, teacher feedback

In recent years, the role of written corrective feedback (CF) has received considerable attention in second language (L2) acquisition research. However, the relationship between such feedback and language learning has been theoretically and empirically controversial. As far as L2 writing is concerned, in several reports, Truscott $(1996,1999,2004,2007)$ claimed that error correction is not only ineffective but also harmful and thus it should be abandoned from L2 writing classrooms. He argued that second language acquisition (SLA) follows a fixed sequence of acquisition and therefore CF may not work. He believed that the knowledge learned through feedback is pseudo-knowledge and that CF undermines students' confidence by negatively impacting the quality of their writing. He also raised practical concerns such as the lack of teachers' metalinguistic knowledge to explain the nature of the error, their inability to recognize students' errors, and students' lack of understanding or motivation to attend to the teacher's feedback.

Truscott's provocative view was countered by a number of researchers (Bitchener, 2008; Bruton, 2009; Chandler, 2004, 2009; Ferris, 1999, 2004, 2010). For example, Ferris (1999) claimed that Truscott interpreted research results without taking into consideration variables such as the research design, the context, the subjects, and the instructional activities. Truscott (1999) responded by reiterating his previous position and also adding that the research base on CF was insufficient, with which Ferris agreed.

These arguments have since led to many experimental and quasiexperimental studies to demonstrate the efficacy of written CF. The studies examined not only the effectiveness of CF in general (e.g., Lalande, 1982; Ferris, 1997; Lee, 1997; Fazio, 2001; Ferris \& Roberts, 2001; Chandler, 2003) but also the effectiveness of different types of CF (e.g., Sheen, 2007; Bitchener \& Knoch, 2008; Al-Rubai'ey \& Nassaji, 2013; Suzuki et al., 2019). The findings of this research have provided evidence that $\mathrm{CF}$ is effective overall. However, significant variations have been noted in the findings, in particular about what type of feedback is most effective. Thus, the debate around the role of written CF and which type of feedback is most effective persists (Ellis, 2017).

However, despite much experimental research on the efficacy of written CF, L2 teachers' written CF practices in intact classrooms are relatively unexplored (Furneaux et al., 2007). While there is a number of descriptive studies that have explored how teachers correct oral errors and how students react to the CF (see for example, Lochtman, 2002; Lyster \& Ranta, 1997; Panova \& Lyster, 2002; Sheen, 2004, 2006; Nassaji, 2007), written CF literature contains few of such studies. In particular, studies comparing the use of feedback across different instructional settings are relatively rare (Guénette \& 
Lyster, 2013). This article reports on a study that examines and compares the use of written CF techniques by English as a second language (ESL) teachers in three different educational contexts: primary, secondary, and college. The study is descriptive in nature in that it aims to document and describe what teachers and students do ${ }^{1}$.

\section{Literature Review}

Corrective feedback refers to strategies that indicate to learners that their output is erroneous in some way, and be provided on oral, written, and technology-mediated output, and in response to a range of errors, including linguistic, content, organization, discourse, and pragmatic errors (Nassaji \& Kartchava, 2017, p. ix). Research, however, has predominantly focused on linguistic errors (Li \& Vuono, 2019).

Feedback can either overtly correct an erroneous form, which is referred to as direct correction or can indicate that an error has been made without providing the correct form, which is referred to as indirect feedback. Direct correction may take various forms, including crossing out superfluous words or phrases, inserting missing words, bracketing misplaced words and indicating their proper place in a sentence, or writing the correct form above the error or in the margin (Ferris, 2006). Indirect correction can be either coded or uncoded feedback. Coded feedback is when the feedback indicates the type of error using a code known to the learners-for example, "SP" for a spelling error. Uncoded feedback indicates the location of the error using techniques such as circling, underlining, inserting arrows or question marks, or counting the number of errors in the margin-but in all cases, leaves the learners to diagnose the error for themselves (Lee, 2004). There is another option available to teachers when providing indirect coded feedback, and that is accompanying the code with a brief grammatical explanation-this is metalinguistic feedback. Guénette (2009), for example, investigated which strategies and techniques pre-service ESL teachers used when providing written $\mathrm{CF}$ and their correlation with the categories of error made by the learners. Her findings revealed that the participants consistently opted for direct corrections.

Both direct and indirect written CF may improve the accuracy of written texts (Ferris, 2010). Less clear, however, is which feedback type is more effective. While direct feedback is viewed to help learners by explicitly indicating the correction and thus enabling them to learn new forms (Ferris \& Hedgcock, 2014), indirect feedback is considered effective in facilitating internalization of already known forms (Bitchener, 2012). Studies that have empirically compared the effects of these feedback types, however, have often produced inconsistent results.

Chandler (2003), for example, compared four types of written CF: correction, underlining and description (underlining errors and providing 
error codes), description only (providing error codes without telling learners where the errors occurred), and underlining only. The results revealed that both direct and indirect correction (underlining) were significantly superior to descriptions for reducing long-term errors. Truscott and Hsu (2008) conducted a study with ESL university students in Taiwan. Their findings revealed that students who received indirect feedback performed better when revising their texts. Karim and Nassaji (2018) examined the effects of comprehensive written corrective feedback on L2 learners' revision accuracy and new pieces of writing. They compared three types of feedback: direct feedback and two types of indirect feedback (underlining only and underlining + metalinguistic cues). All three feedback types significantly improved students' revisions. Some notable but non-significant effects were also observed for direct and underlining + metalinguistic feedback on new pieces of writing. Suzuki et al. (2018) examined the effects of different direct and indirect feedback on learning English articles and past perfect. They found an effect for indirect feedback, but also reported a mediating role for error type. For example, of the two target structures examined, the effect of indirect feedback was more pronounced on the past perfect tense than on articles. More recently Kim et al. (2020) compared the impact of direct and indirect written CF on 53 beginner learners of L2 Korean targeting 12 linguistic features. They found that direct written $\mathrm{CF}$ was more useful in helping students produce accurate writing, but both feedback types were effective in promoting the learning of new linguistic features through collaborative writing.

The variations in the above findings suggest that $\mathrm{CF}$ is a multidimensional practice that can be influenced by a variety of factors (Chen et al., 2016; Kormos, 2012; Ellis, 2009). Some of these factors include the category of error (syntax, spelling, or vocabulary), the nature of the feedback, and learnerspecific variables (motivation, aptitude, skill level, learning disabilities, and age). Another important variable can be the context of instruction. Housen et al. (2011) distinguished three broad, overlapping, and intersecting contexts in L2 teaching and learning. The first is the learners' individual learning context. This microlevel context is shaped by, among other factors, the learners' individual needs, orientations, preferences, abilities, knowledge, personality traits, social networks, and discourse-interactional practices. The second level corresponds to the language classroom or, more generally, the curricular context. The curricular context is shaped by the school's ethos and language policy, as well as by wider institutional factors such as the prevailing educational policy, and its implementation in terms of the structure of the education system, curriculum design, and pedagogical approaches and methods prescribed or advocated. These factors, in turn, determine classroom practices in terms of the didactic methods and activities used as well as the resources available for language teaching. This has strong implications for student and teacher roles and relations, students' attention, and input and output opportunities created in the language classroom. The third (and 
broadest) level of the learning context is the extracurricular context, which comprises the wider demographic, cultural, and institutional context both inside and outside the school that are beyond the direct control of curricular intervention. Example of this broader context would be ESL versus English as a foreign language (EFL) context, or primary, secondary, and college contexts. Clearly, the instructional context in which learners learn a language can play an important role in how they learn a second language. Nonetheless, we know little about the specific impact of context on L2 development. Even when we consider a classroom context, there are many factors that can influence the provision and usefulness of feedback and instruction, including the teacher, the lesson, and the nature of the task (Sheen, 2004). Therefore, it is important to find out how students and teachers behave in different instructional contexts with respect to corrective feedback and whether the provision and usefulness of feedback differ across contexts.

There are currently a few studies that have examined the role of instructional context and levels in corrective feedback, but they have been mostly on oral feedback (e.g., Lyster \& Mori, 2006; Oliver, 2000; Mackey et al., 2003, Sheen, 2004). For example, in a descriptive study, Sheen (2004) compared the extent to which teachers' oral CF and learners' uptake varied across four communicative classroom contexts (French Immersion, Canada ESL, New Zealand ESL, and Korean EFL). Sheen found that recast was the most frequent feedback type in all four contexts, but they were much more frequent in the Korean EFL and New Zealand ESL classrooms than in the Canadian Immersion and ESL classrooms. She also found that both uptake and repair were much more prevalent in the ESL and EFL settings involving educated adults than in the immersion setting with children and in the ESL setting with less educated learners. Oliver (2000) examined whether differences exist in the provision and use of corrective feedback according to the age of the learners and the context of interaction. Her findings showed that the pair-work context as opposed to a teacher-fronted context led to more feedback moves, whereas the actual use of CF by the learners was greater in teacher-fronted interaction. Furthermore, children were more likely to use such feedback than adults, suggesting that pedagogical context and age play an important role in CF and learner responses to CF. Lyster and Mori (2006) compared oral feedback in two different instructional settings: a French immersion and a Japanese immersion context. Their study showed a frequent use of recasts in both contexts. However, the patterns of students' uptake and repair in response to feedback differed in the two settings, with most of the repair happening after prompts in French immersion but after recasts in Japanese immersion.

The findings that CF helps learners' accuracy in general indicate that it is important to recognize its place in the L2 classroom. However, the variations in results suggest that we need to explore the CF practices in more detail and in various contexts (Bitchener \& Ferris, 2012). Furthermore, given the scarcity 
of such research on written feedback, this study explored and compared the provision and usefulness of written $\mathrm{CF}$ across three different educational contexts and levels: primary, secondary, and college levels. It addressed the following three research questions:

1. How do the types of errors ESL students make vary across primary, secondary, or college levels?

2. What kinds of corrective feedback do teachers provide, and do the feedback types vary across the three levels?

3. To what extent do students revise their texts following teacher feedback, and do the revisions vary across the three levels?

\section{Method}

\section{Research Context and Participants}

The study was conducted within the context of the Quebec educational system. This system includes public and private institutions in both the Francophone and Anglophone sectors. It covers four educational levels: (a) primary, (b) secondary, (c) college (CÉGEP), and (d) university. Preschool education is optional, but the vast majority of children enroll in such programs. We did not include the university level because we did not have access to universitylevel learners.

The primary education consists of six years of schooling divided into three cycles of two years each, whereas the secondary level offers five years of general education divided into two cycles. The International Baccalaureate (IB) is offered to students in Grades 11 and 12. College constitutes an intermediary level between compulsory primary and secondary education and university. The general and vocational colleges are known as CÉGEPs, a French acronym for Collège d'enseignement général et professionnel. CÉGEPs offer two-year preuniversity programs and three-year technical programs leading to a Diploma of College Studies.

Our study was conducted in two primary, two secondary, and two college-level classes. For the primary level, we chose Grade 6 students because students in this grade are expected to write short texts as part of the development of Competency 3 (which is the ability to write). As for the secondary students, Grade 8 and Grade 10 were recruited because of the availability and interest of the participating teachers. College students were also recruited based on accessibility. As Table 1 shows, the number of students in the participating classes was 128 (primary, $n=39$; secondary, $n=$ 45; and college, $n=44$ ). There were 69 females and 59 males, whose mean age ranged from 12 to 19, and French was the first language (L1) for most of the students across the three levels (primary $84 \%$, secondary $89 \%$, college $88 \%$ ) (see Table 1 for additional information). 
Table 1

Participant Students' Background

\begin{tabular}{|c|c|c|c|c|}
\hline & & Primary & Secondary & College \\
\hline Number & & 39 & 45 & 44 \\
\hline \multirow[t]{2}{*}{ Gender } & Female & 23 & 23 & 23 \\
\hline & Male & 16 & 22 & 21 \\
\hline \multirow[t]{2}{*}{ Age } & Mean & 12 & 15 & 19 \\
\hline & SD & 0.5 & 0.5 & 0.9 \\
\hline French L1 & & 33 (84\%) & 40 (89\%) & $39(88 \%)$ \\
\hline English L1 & & $2(5 \%)$ & $2(4 \%)$ & $2(5 \%)$ \\
\hline Bilingual & & $1(3 \%)$ & $2(5 \%)$ & $2(5 \%)$ \\
\hline Other languages & & $3(8 \%)$ & $1(2 \%)$ & $1(2 \%)$ \\
\hline
\end{tabular}

As for the participant teachers, there were six teachers, five females and one male, between the ages of 32 and 59. Two of them taught at the primary level, two at the secondary level, and two at the college level. Two of the teachers considered English their first language, three self-identified as French native speakers, and one reported being a English-French bilingual. Three of the teachers spoke languages other than English and French (i.e., Spanish, Farsi, Romanian, and Dutch). Regarding professional background, only one teacher held a degree in TESL. The other five held bachelor's degrees in primary $(n=2)$, secondary $(n=2)$, and French as a second language $(n=1)$ education. 


\section{Data Collection Procedures}

As part of their routine classroom activities, the students first produced an initial draft of a text, on which the teachers provided feedback. Following this, the students revised their text. Since the data were collected as part of the classroom routine activities, the choice of topic, length, and the amount of time given to compose the text were decided by the teacher and varied from level to level. Primary participants had 30 minutes to write a letter (100 words) to a fictional penfriend. To facilitate their writing, the teacher asked students to reply to the following prompt: "In your next letter, please tell me all about your favourite TV program. Why do you like watching it? What's it about?" Secondary and college participants had 50 minutes to write a 140to 190-word essay about the environment in accordance with the following written instructions: "In your English class, you have been talking about the environment. Now, your English teacher has asked you to write an essay. Write an essay based on the following topic. Use the notes given and provide reasons for your point of view: 'Every country in the world has problems with pollution and damage to the environment. Do you think these problems can be solved? Notes: Write about: (1) transport, (2) rivers and seas, (3) . . (your own idea).'”

The teachers collected the writings and corrected them. In the following class session, students received their compositions back and were asked to revise them, creating a second draft that took into consideration the corrections they had received. The teacher collected both initial and revised drafts and submitted them to us.

\section{Data Analysis}

In order to address the research questions, the students' written productions were analyzed and coded in terms of types of errors made by students, CF techniques the teachers used, and students' revisions. Students' error types were coded using an adapted version of Guénette and Lyster's (2013) typology. Guénette and Lyster developed a list of 13 errors types: determiners, mechanics (punctuation, capitalization), style, first language use, noun endings (singular/plural), prepositions, spelling, sentence structure, agreement (subject/verb, noun/adjective, determiner/noun), verbs (verbs forms and auxiliaries), word choice, word order, and missing word. We grouped these error types into five categories: Lexical, Grammatical, Mechanics, L1 Use, and Spelling (see Table 2). We excluded "style" from our list of errors as there were very few stylistic errors and our primary focus was on language forms. 
Table 2

Types of Errors (adapted from Guénette \& Lyster, 2013)

Type of error category

Description

a) Lexical

- Determiners the, $a$, an

Missing determiner

Wrong determiner

- Word choice

Wrong word choice

(e.g., raining cats and rats [dogs])

- Word form

Wrong word choice

(e.g., exciting vs. excited)

- Word missing

Absence of a word from the place where it was expected to be found

- Prepositions

Wrong preposition

Missing preposition

Extra preposition

b) Grammar

- Sentence structure

Grammatical arrangement of words. Includes agreement (subject-verb, noun-pronoun, nounadjective, determiner-noun and article-noun) and question formation.

- Verbs

Problems with verb forms

Problems with verb tenses

c) Mechanics

- Punctuation

Incorrect use of punctuation marks

- Capitalization

Incorrect use of capital letters

d) L1 Use

Use of a French (L1) word (e.g.,"vacance" instead of "holidays"). Literal translation of a French structure or expression, resulting in a calque (e.g., "he learns me" translated from "il m'apprend")

e) Spelling

Incorrect spelling

The types of corrective feedback strategies the teachers used were coded using the error correction categories adapted from Guénette (2009). Direct feedback was divided into two subcategories (with and without comments) 
whereas indirect feedback was divided into four subcategories: clarification requests, indirect error identification, indirect error identification with error code and indirect error identification with comments (see Table 3).

Table 3

Types of Corrective Feedback (adapted from Guénette, 2009).

\begin{tabular}{cc}
\hline $\begin{array}{c}\text { Type of corrective } \\
\text { feedback category }\end{array}$ & Description \\
\hline
\end{tabular}

A) Direct Direct error with no The correct form is provided with no comments comments

Direct error correction with The correct form is provided with comments. comments

B) Indirect Clarification requests

The teacher asks a question to understand what the student means

Indirect error identification

The error is underlined, highlighted, or coloured differently without providing the correct form

Indirect error identification with error codes

The teacher uses codes without providing the correct form.

Indirect error identification

Next to the error, in a commentary bubble or with comments outside of text without providing the correct form.

Finally, students' responses to CF were analyzed using the categories adapted from Ferris (2006). As can be seen in Table 4, Ferris proposed three types of successful revisions (error corrected, correct substitution, and averted erroneous teacher marking) and four types of unsuccessful revisions (incorrect change, deleted text, incorrect substitution, and teacher-induced error). 
Table 4

Students' Types of Revisions

Type of revision category

Description

Error corrected

Incorrect change

Deleted text

Substitution, correct

Substitution, incorrect

Teacher-induced error

Averted erroneous teacher marking
Error corrected as per teacher's marking

Change was made, but incorrectly

Student removed the marked text

Student correctly made a change that was not suggested by the teacher's marking

Student incorrectly made a change that was not suggested by the teacher's marking

Incomplete or misleading teacher marking caused the student error

Student corrected the error despite incomplete or erroneous teacher marking

To ascertain inter-rater reliability, one of the authors and a research assistant independently coded a subset (40 of the 250) of the first and revised drafts; the analysis resulted in a $96 \%$ agreement on each category (students' errors, teachers' feedback, and students' revisions). The rest of the papers ( $n$ $=210)$ were divided between one of the authors and the research assistant $(n$ $=105$ each) and analyzed separately.

\section{Results}

The first research question concerned the types of errors students made and if these varied across the primary, secondary, and college-level learners. As can be seen in Table 5, there were notable differences across the levels, with grammatical errors dominating. However, lexical errors occurred more frequently at the college (35\%) and secondary level (24\%) L1 errors compared to those at the primary level (14\%); mechanics errors were the least frequent types across the three levels. The chi square showed that these differences were statistically significant $\left(X^{2}[8, N=128]=254.54, p<.001\right)$. 
Table 5

Types of Errors

\begin{tabular}{lllllll}
\hline & \multicolumn{5}{c}{ Types of error } \\
& L1 & Grammatical & Lexical & Mechanics & Spelling & Total \\
\hline Primary & 71 & 778 & 203 & 196 & 219 & 1467 \\
& $5 \%$ & $53 \%$ & $14 \%$ & $13 \%$ & $15 \%$ & $100 \%$ \\
Secondary & 20 & 159 & 100 & 29 & 111 & 419 \\
& $5 \%$ & $38 \%$ & $24 \%$ & $7 \%$ & $26 \%$ & $100 \%$ \\
& & & & & & \\
College & 29 & 455 & 342 & 32 & 107 & 965 \\
& $3 \%$ & $47 \%$ & $35 \%$ & $4 \%$ & $11 \%$ & $100 \%$ \\
& & & & & & \\
Total & 120 & 1392 & 645 & 257 & 437 & 2851 \\
& $4 \%$ & $49 \%$ & $23 \%$ & $9 \%$ & $15 \%$ & $100 \%$ \\
\hline
\end{tabular}

The second research question concerned the different written corrective feedback techniques the teachers used and whether they varied according to educational context. As Table 6 shows, the most frequent type of feedback was direct correction with no comments $(44 \%)$ followed by error identification with codes $(23 \%)$. Clarification requests was the least common feedback type (1\%).

Table 6

Types of Feedback Overall

\begin{tabular}{llll}
\hline & \multicolumn{1}{c}{ Types of feedback } & $f$ & $\%$ \\
\hline \multirow{2}{*}{ Direct } & Direct correction & 1253 & $44 \%$ \\
& Direct error correction with comment & 69 & $2 \%$ \\
\hline \multirow{2}{*}{ Indirect } & Clarification requests & 23 & $1 \%$ \\
& & & \\
& Indirect error identification (underlining, colour coding) & 476 & $17 \%$ \\
& Indirect error identification with error code & 659 & $23 \%$ \\
& Indirect error identification with comment & 153 & $5 \%$ \\
\hline Ambiguous & & 218 & $8 \%$ \\
Total & & 2851 & $100 \%$ \\
\hline
\end{tabular}


Table 7 groups feedback strategies into two major types (direct and indirect) and shows their distribution across levels. As can be seen, the use of the two feedback types differed. While the primary and secondary teachers provided more direct feedback $(62 \%$ and $75 \%$, respectively), teachers at the college level supplied mostly indirect feedback $(76 \%)$. The chi-square test showed that this difference was statistically significant $\left(X^{2}[2, N=2633]=\right.$ $426.63, p<.001)$.

Table 7

Types of Feedback Across Levels

\begin{tabular}{llll}
\hline & \multicolumn{2}{c}{ Type of feedback } & \\
& Indirect & Direct & Total \\
\hline Primary & 489 & 796 & 1285 \\
& $38 \%$ & $62 \%$ & $100 \%$ \\
Secondary & 100 & 297 & 397 \\
& $25 \%$ & $75 \%$ & $100 \%$ \\
College & 722 & 229 & 951 \\
& $76 \%$ & $24 \%$ & $100 \%$ \\
Total & 1311 & 1322 & 2633 \\
& $50 \%$ & $50 \%$ & $100 \%$ \\
\hline
\end{tabular}

Table 8 shows the subtypes of direct and indirect feedback. For direct feedback, the most common subtype was direct correction with no comments. This, however, was supplied most often to secondary school students. Correction with metalinguistic explanation and clarification questions were rare for these students. Of the four indirect feedback subtypes, error identification with codes was most often provided to college students. Indirect feedback was supplied least often to secondary school students. The chi-square test showed that the relationship between educational levels and the occurrence of feedback types was statistically significant $\left(X^{2}[8, N=2881]\right.$ $=257.7, p<.001$ ). 
Table 8

Categories of Indirect and Direct Feedback Types

\begin{tabular}{lllllllll}
\hline & \multicolumn{7}{c}{ Direct feedback } & \multicolumn{7}{c}{ Indirect feedback } \\
& Dw/c & D & Total & CR & IU & Iw/c & IC & Total \\
\hline Primary & 36 & 760 & 796 & 2 & 377 & 71 & 39 & 489 \\
$(n=39)$ & $5 \%$ & $95 \%$ & $100 \%$ & $0.4 \%$ & $77 \%$ & $15 \%$ & $8 \%$ & $100 \%$ \\
& & & & & & & & \\
Secondary & 27 & 270 & 297 & 4 & 81 & 6 & 9 & 100 \\
$(n=45)$ & $9 \%$ & $91 \%$ & $100 \%$ & $4 \%$ & $81 \%$ & $6 \%$ & $9 \%$ & $100 \%$ \\
& & & & & & & & \\
College & 6 & 223 & 229 & 17 & 18 & 76 & 611 & 722 \\
$(n=44)$ & $3 \%$ & $97 \%$ & $100 \%$ & $2 \%$ & $3 \%$ & $10 \%$ & $85 \%$ & $100 \%$ \\
Total & 69 & 1253 & 1322 & 23 & 476 & 153 & 659 & 1311 \\
$(n=128)$ & $5 \%$ & $95 \%$ & $100 \%$ & $2 \%$ & $36 \%$ & $12 \%$ & $50 \%$ & $100 \%$ \\
\hline
\end{tabular}

Note: Clarification requests (CR), indirect error identification (IU), indirect error identification with comment, question or explanations (I w/c), indirect error identification with error code (IC), direct error correction with metalinguistic explanations (Dw/c), direct error correction without comment (D).

The third research question addressed the extent to which students were able to revise their texts in response to teacher feedback, and whether the revisions varied across levels. As Table 9 shows, students were able to correct their errors at a notable rate $(74 \%)$, but the revisions varied across the three levels. For example, secondary and college students made more successful revisions ( $83 \%$ and $82 \%$, respectively) than the primary students $(63 \%)$. Incorrect changes and no changes were also made more frequently by the primary students (incorrect: $13 \%$; no change $7 \%$ ) than the secondary (incorrect 3\%; no change 4\%) and college students (incorrect change 9\%; no change $3 \%$ ). In terms of the teacher-induced errors, the primary students presented the highest frequency $(10 \%)$. The chi square showed that these differences in revision were statistically significant across contexts $\left(X^{2}[14, N\right.$ $=1721]=120.03, p<.001$ ). 
Table 9

Revision Across Levels

\begin{tabular}{|c|c|c|c|c|c|c|c|c|c|}
\hline \multicolumn{10}{|c|}{ Type of revision } \\
\hline & AETM & DT & EC & IC & $\mathrm{NC}$ & SC & SI & TIE & Total \\
\hline \multirow[t]{2}{*}{ College } & 4 & 4 & 502 & 56 & 26 & 8 & 5 & 11 & 616 \\
\hline & $1 \%$ & $1 \%$ & $82 \%$ & $9 \%$ & $3 \%$ & $1 \%$ & $1 \%$ & $2 \%$ & $100 \%$ \\
\hline \multirow[t]{2}{*}{ Primary } & 3 & 33 & 480 & 97 & 56 & 7 & 11 & 79 & 766 \\
\hline & $1 \%$ & $4 \%$ & $63 \%$ & $13 \%$ & $7 \%$ & $1 \%$ & $1 \%$ & $10 \%$ & $100 \%$ \\
\hline \multirow[t]{2}{*}{ Secondary } & 1 & 4 & 286 & 11 & 12 & 5 & 4 & 16 & 339 \\
\hline & $1 \%$ & $1 \%$ & $83 \%$ & $3 \%$ & $4 \%$ & $2 \%$ & $1 \%$ & $5 \%$ & $100 \%$ \\
\hline \multirow[t]{2}{*}{ Total } & 8 & 41 & 1268 & 164 & 94 & 20 & 20 & 106 & 1721 \\
\hline & $1 \%$ & $2 \%$ & $74 \%$ & $10 \%$ & $5 \%$ & $1 \%$ & $1 \%$ & $6 \%$ & $100 \%$ \\
\hline
\end{tabular}

Note: AETM (Averted Erroneous Teacher Marking), DT (Deleted Text), EC (Error Corrected) IC (Incorrect Change), NC (No Change), SC (Substitution Correct), SI (Substitution Incorrect), TIE (Teacher-Induced Error)

\section{Discussion}

This study examined the occurrence and effectiveness of written corrective feedback techniques used by ESL teachers in their classes. The aim was to examine whether there were any differences in the types of errors made, the kind and degree of feedback provided, as well as the students' ability to incorporate the feedback while revising their texts across primary, secondary, and college levels.

The results showed that grammatical errors were the most frequent error type followed by lexical and spelling errors. However, these types of errors varied across the three educational levels. For example, college students made more lexical errors (35\%) than those at the secondary $(24 \%)$ and primary $(14 \%)$ levels. College students produced significantly fewer spelling errors than the secondary students ( $11 \%$ and $26 \%$, respectively). Our post-hoc analysis further revealed that the subtypes of grammatical errors also varied across levels. At the primary level, for example, the most common errors concerned sentence structure agreement (noun-adjective, subject-verb). At the secondary level, however, agreement between determiners and nouns was the most frequent error type. In college, sentence structure agreement errors (noun-pronoun), question formation issues, and problems with verb tenses were most frequent. One reason for the variations in types of errors could be partly due to the differences in the writing tasks used at each level. 
This explanation is consistent with studies that have shown an effect for task type. For example, Way et al. (2000) explored L2 French learners' performance on three task types (descriptive, narrative, and expository writing) and found differences in accuracy, with the descriptive writing being more accurate than expository writing. Using three types of prompts (bare prompt consisting of simple explanation of the task, prompt with a list of vocabulary, and prompt that provided a prose model), the study also found an effect for types of writing prompts, with the prose model prompt leading to more accurate text than the other types of prompt. Since our study was conducted in intact classrooms with no intervention, the tasks used were determined by the teacher. Primary students wrote a narrative text whereas secondary and college students wrote an argumentative essay. These two tasks have different characteristics. The narrative task entails an event description with a focus on people's actions in a specific time frame and its primary aim is to tell an interesting story, whereas the argumentative task involves the use of claims, justifications, and warrants to convince readers one way or another. These differences could have led to the use of different language forms and structures, hence resulting in different errors. Another reason for variation in the type of errors could be the learners' level of language proficiency (see Nassaji, 2015, 2016). We did not measure the students' level of language proficiency in any systematic way, but if we assume that the students at the primary level had lower levels of language proficiency than college-level students, the results can be taken to show that lower-level students made more lexical and grammatical errors whereas higher-level students made more morphosyntactic errors. Therefore, the above explanation is speculative and future studies should examine the relationship between error types and the learners' levels of language proficiency.

As for feedback types, students received different types of feedback and the types of feedback varied across the primary, secondary, and college levels. While both primary and secondary students received more direct than indirect feedback, college students received more indirect feedback. The use of direct correction at the secondary level was consistent with previous research. Lee (2004), for example, reported that more than half of the errors identified by secondary-level EFL teachers were corrected directly, and that the only other indirect feedback strategy used was indicating the locations of errors with codes. In the same vein, Furneaux et al. (2007), examining the feedback practices of ESL teachers in secondary schools from five countries, found that they responded to learner errors mostly through direct correction. Part of the reason for this could be that teachers may find direct correction more useful for beginner-level learners but feel that indirect feedback is sufficient for advanced learners who may be better able to make use of their linguistic repertoire to discern their own errors (Bitchener, 2012; Ellis, 2009; Ferris, 2010). 
Our results also showed that the teachers' choice of feedback varied according to the type of errors. For example, while errors of grammar and mechanics received more direct feedback, lexical and spelling errors resulted in more indirect feedback. This finding aligns with Ferris (2006) that showed spelling errors receiving more indirect feedback. This finding could be partly explained by the teachers' understanding of the correctability of lexical versus grammatical errors (Truscott, 2001). Since there are no specific rules to follow in order to avoid lexical errors, the teachers might have chosen direct correction, whereas they may have felt more comfortable encouraging students to self-correct, especially at the college level, where students are supposed to possess a larger vocabulary base (Levitzky-Aviad \& Laufer, 2013).

Finally, our results showed that participants at the secondary and college levels were more successful than primary students in correcting their own errors when revising their texts (secondary and college students produced $83 \%$ and $82 \%$ successful revisions, respectively, whereas primary students successfully revised $63 \%$ of the texts). Incorrect changes and no changes were also more frequent among the primary than college students. These findings suggest that students' revisions are not the same across contexts and can vary depending on learners' educational levels. There could be a number of reasons for these variations. One could be differences in the nature of errors. As noted earlier, primary-level students made more grammatical errors whereas secondary- and college-level students made more lexical errors. Previous research has shown a relationship between error types and students' revision. Mackey et al. (2000), for example, found that lexical errors were noticed more readily than syntactic or morphosyntactic errors. Another reason could be differences in the learners' age. Research on oral feedback has shown that adult learners revise their errors more successfully than children do (Mackey et al., 2003; Oliver, 2000). The primary students in our study were not children in that sense of the term, but they were younger. Thus, it is possible that their age differences could have attributed to how they responded to the feedback. Learner language proficiency may be another reason. Research has shown a close relationship between language proficiency and learners' incorporation of feedback. Park et al. (2015), for example, found that although all learners in their study were able to self-correct more than a third of their errors, the intermediate- level learners were better able to remedy their errors than beginners. As noted earlier, since this study was conducted in intact classess, we did not use a measure of language proficiency to group learners into low or high language proficiency learners. But if we assume that learners who were at the primary level were less proficient, we could speculate that part of the reason for the differences in learners' responses to feedback could be related to differences in language proficiency (Kang \& Han, 2015; Karim \& Nassaji, 2019). 
Another interesting finding was the occurence of teacher-induced errors. Although the percentage was small, it occurred and was also most common among primary students. This could have been due to incomplete or misleading teacher markings, which could have led to student errors. This suggests that teachers are not always consistent and accurate in their correction strategies, which might be partially due to their inability to always accurately recognize the sources of students' errors (Ferris, 1999). This also alignes with Lee's (2004) finding that only slightly over half of the teachers' error feedback was accurate $(57 \%)$, and the other half was either mainly unnecessary or in some cases inaccuarate. Undoubtedly when the teacher feedback is inaccurate, it would be not only unhelpful but also misleading (Ferris, 1999; Lee, 2004), which then suggests that teachers should be careful when correcting learner errors and should try to be clear and consistent to avoid confusion.

\section{Conclusion and Implications}

This study examined and compared different written corrective feedback techniques used by ESL teachers at three different educational levels: primary, secondary, and college. Findings revealed important differences across levels. They showed that (a) as learners moved from primary to secondary and college levels, the frequency of grammatical errors decreased and the frequency of lexical errors increased; (b) primary and secondary students received more direct than indirect feedback, while college students received more indirect feedback; and (c) secondary and college students make more corrections than primary students. These findings are pedagogically valuable and suggest that teachers should pay special attention to their learners' educational context and levels. Likewise, teachers should be mindful when choosing the type of feedback to provide. As Ellis (2009) pointed out, teachers may often respond to learner errors intuitively rather than based on a wellguided correction policy. However, it is important that they recognize the complexity of corrective feedback and how its effectiveness may interact with various factors. For example, the findings that participants at the secondary and college levels made different types of errors and also differed in the degree of revisions reflect the importance for teachers to consider context and types of errors when providing feedback. Thus, it is essential that teachers be mindful of how feedback effectiveness may be influenced by these factors.

However, the study has some limitations that should be considered when interpreting the results. First, the results of this study are based on one writing task at each level. This may not have been enough to adequately engage the participants in the writing and feedback process. Further research could be carried out to include more writing tasks in longitudinal studies, allowing the examination of students' revision and transfer to new pieces of writing. Second, this research was descriptive, as it attempted to document 
and describe characteristics of the observed data (which in our study were students' errors, teachers' feedback, and students' response to the feedback) with no intervention and manipulation of variables. This type of research, carried out in real classrooms with real learners and teachers, has a greater potential to inform classroom practice; it presents a higher degree of ecological validity than research carried out in a laboratory. Since descriptive studies examine relationships as they exist, they do not make any cause and effect claims. Thus, to examine cause and effect relationship, future studies which are experimental in nature and conducted in more controlled conditions are needed.

\section{Notes}

1. Descriptive research is observational and thus differs from experimental research, which is interventional and manipulates variables, calling them dependent and independent variables (Seliger \& Shohamy, 1989).

\section{Acknowledgement}

We are grateful to the guest editors and anonymous reviewers of this special issue for their helpful feedback on earlier versions of this manuscript.

\section{The Authors}

Maria-Lourdes Lira-Gonzales is professor and chair of the Teaching English as a Second Language (TESL) Program at the Université du Québec en Abitibi-Témiscamingue. Her research interests include corrective feedback and the impact of ICTs (Information and Communication Technologies) in foreign and second language writing.

Hossein Nassaji is professor of applied linguistics in the Department of Linguistics at the University of Victoria, Victoria, BC. His teaching and research interests include second language acquisition, corrective feedback, form-focused instruction, task-based teaching, classroom discourse, and the application of sociocultural theories to second language research and pedagogy.

\section{References}

Al-Rubai'ey, F., \& Nassaji, H. (2013). Direct and indirect metalinguistic feedback: A matter of suitability rather than superiority. In M. Mahmoud \& R. Al Mahrooqi (Eds.), Issues in TEFL in the Arab World (pp. 28-43). Muscat, Oman: Sultan Qaboos University Press.

Bitchener, J. (2008). Evidence in support of written corrective feedback. Journal of Second Language Writing, 17, 102-118. http://jimelwood.net/students/grips/tables_figures/bitchener_2008.pdf

Bitchener, J. (2012). A reflection on 'the language learning potential' of written CF. Journal of Second Language Writing, 21, 348-363.

Bitchener, J., \& Ferris, D. R. (2012). Written corrective feedback in second language acquisition and writing. Routledge. DOI: https://doi.org/10.1017/S0272263112000733

Bitchener, J., \& Knoch, U. (2008). The value of written corrective feedback for migrantand international students. Language Teaching Research Journal, 12, 409-31. https:// doi.org/10.1177/1362168808089924

Bruton, A. (2009). Improving accuracy is not the only reason for writing, and even if it were... 
System, 37, 600-613. https://doi.org/10.1016/j.system.2009.09.005

Chandler, J. (2003). The efficacy of various kinds of error feedback for improvement in the accuracy and fluency of L2 student writing. Journal of Second Language Writing, 12, 267-296.

Chandler, J. (2004). A response to Truscott. Journal of Second Language Writing, 13(4), 345-348. https://www.sciencedirect.com/journal/journal-of-second-language-writing/vol/13/issue/4

Chandler, J. (2009). Response to Truscott. Journal of Second Language Writing, 18, 57-58. DOI: 10.1016/j.jslw.2008.09.002

Chen, S., Nassaji, H., \& Liu, Q. (2016). EFL learners' perceptions and preferences of written corrective feedback: A case study of university students from Mainland China. Asian-Pacific Journal of Second and Foreign Language Education, 1, 1-5. https://doi.org/10.1186/s40862-016$0010-\mathrm{y}$

Ellis, R. (2009). A typology of written corrective feedback types. ELT Journal, 63, 97-107.

Ellis, R. (2017). Oral corective fedback in L2 clasroms: What We Know so Far. In H. Nassaji \& E. Kartchava (ED.,) Corrective feedback in second language teaching and learning: Research, theory, applications, implications (pp. 3-18). Milton Park, Abingdon, Oxon;New York;: Routledge.

Fazio, L. (2001). The effects of corrections and commentaries on journal writing of minorityand majority-language minorities. Journal of Second Language Writing, 10, 235-49. https://doi. org/10.1016/S1060-3743(01)00042-X

Ferris, D. (1997). The influence of teacher commentary on student revision. TESOL Quarterly, 31, 315-39. https://doi.org/10.2307/3588049

Ferris, D. (1999). The case for grammar correction L2 writing classes: A response to Truscott. Journal of Second Language Writing, 8, 1-11. https://doi.org/10.1016/S1060-3743 (99)80110-6

Ferris, D. (2004). The "grammar correction" debate in L2 writing: Where we are, and where do we go from here? (and what do we do in the meantime ...?). Journal of Second Language Writing, 13, 49-62. DOI: 10.1016/j.jslw.2004.04.005

Ferris, D. (2006). Does error feedback help student writers? New evidence on the short-and long-term effects of written error correction. In K. Hyland \& F. Hyland (Eds.), Feedback in second language writing (pp.81-104). Cambridge, England: Cambridge University Press. DOI: https://doi.org/10.1017/9781108635547.008

Ferris, D. (2010). Second language writing research and written corrective feedback in SLA: Intersections and practical applications. Studies in Second Language Acquisition, 32, 181-201. DOI: https://doi.org/10.1017/S0272263109990490

Ferris, D., \& Hedgcock, J. S. (2014). Teaching L2 composition: Purpose, process, and practice (3rd ed.). Routledge.

Ferris, D., \& Roberts, B. (2001). Error feedback in L2 writing classes: How explicit does it need to be? Journal of Second Language Writing, 10, 161-84. https://doi.org/10.1016/S10603743(01)00039-X

Furneaux, C., Paran, A., \& Fairfax, B. (2007). Teacher stance as reflected in feedback on student writing: An empirical study of secondary school teachers in five countries. International Review of Applied Linguistics in Language Teaching, 45, 69-94. DOI: 10.1515/IRAL.2007.003

Guénette, D. (2009). The cyberscript project: A mixed-method study of pre-service ESL teachers' corrective feedback beliefs and practices [Doctoral dissertation]. McGill University. https://pdfs. semanticscholar.org/fa1c/7e70794f55df6ad0e21a82c3cd125ba895c9.pdf

Guénette, D., \& Lyster, R. (2013). The written corrective feedback practices of pre-service ESL teachers. La revue canadienne des langues vivantes, 69, 1-25. http://digitool.library.mcgill.ca/ webclient/StreamGate?folder_id=0\&dvs=1575223595127 405

Housen, A., Schoonjans, E., Janssens, S., Welcomme, A., Schoonheere, E., \& Pierrard, M. (2011). Conceptualizing and measuring the impact of contextual factors in instructed SLA: The role of language prominence. International Review of Applied Linguistics in Language Teaching, 49(2), 83. doi:10.1515/iral.2011.005

Kang, E., \& Han, Z. (2015). The efficacy of written corrective feedback in improving L2 written accuracy: A meta-analysis. The Modern Language Journal, 99, 1-18. 
Karim, K., \& Nassaji, H. (2018). The revision and transfer effects of direct and indirect comprehensive corrective feedback on ESL students' writing. Language Teaching Research: LTR, 24(4), 136216881880246-539. doi:10.1177/1362168818802469

Karim, K., \& Nassaji, H. (2019). The effects of written corrective feedback: A critical synthesis of past and present research. Instructed Second Language Acquisition, 3, $28-52$.

Kim, Y., Choi, B., Kang, S., Kim, B., \& Yun, H. (2020). Comparing the effects of direct and indirect synchronous written corrective feedback: Learning outcomes and students' perceptions. Foreign Language Annals, 53(1), 176-199. doi:10.1111/flan.12443

Kormos J. (2012). Differences across modality of performance: An investigation of linguistic and discourse complexity in narrative tasks. Task-based L2 language learning: Insights from and for L2 writing. Amsterdam: John Benjamins.

Lalande, J. F. (1982). Reducing composition errors: an experiment. Modern Language Journal, 66, 140-9. https://doi.org/10.1111/j.1540-4781.1982.tb06973.x

Lee, I. (1997). ESL learners' performance in error correction in writing: Some implications for college-level teaching. System, 25, 465-77. https://doi.org/10.1016/s0346-251x(97)00045-6

Lee, I. (2004). Error correction in L2 secondary writing classrooms: The case of Hong Kong. Journal of Second Language Writing, 13, 285-312. https://doi.org/10.1016/j.jslw.2004.08.001

Levitzky-Aviad, T., \& Laufer, B. (2013). Lexical properties in the writing of foreign language learners over eight years of study: Single words and collocations. In C. Bardel, C. Lindqvist, \& B. Laufer (Eds.), L2 Vocabulary acquisition, knowledge and use: New perspectives on assessment and corpus analysis (pp. 127-148). EUROSLA-the European Second Language Association.

Li, S., \& Vuono, A. (2019). Twenty-five years of research on oral and written corrective feedback in system. System, 84, 93-109. doi:10.1016/j.system.2019.05.006

Lochtman, K. (2002). Oral corrective feedback in the foreign language classroom: How it affects interaction in analytic foreign language teaching. International Journal of Educational Research, $37,271-283$.

Lyster, R., \& Mori, H. (2006). Interactional feedback and instructional counterbalance. Studies in Second Language Acqusition, 28(2), 269-300.

Lyster, R., \& Ranta, L. (1997). Corrective feedback and learner uptake. Studies in Second Language Acquisition, 19, 37-66.

Mackey, A., Gass, S., \& McDonough, K. (2000). How do learners perceive interactional feedback? Studies in Second Language Acquisition, 22(4), 471-497.

Mackey, A., Oliver, R., \& Leeman J. (2003). Interactional input and the incorporation of feedback: An exploration of NS-NNS and NNS-NNS adult and child dyads. Language Learning, 53(1), 35-66.

Nassaji, H. (2007). Elicitation and reformulation and their relationship with learner repair in dyadic interaction. Language learning, 57(4), 511-548.

Nassaji, H. (2015). Interactional feedback dimension in instructed second language learning. London: Bloomsbury Publishing.

Nassaji, H. (2016). Anniversary article: Interactional feedback in second language teaching and learning: A synthesis and analysis of current research. Language Teaching Research, 20, 535-562.

Nassaji, H., \& Kartchava, E. (2017). The role of corrective feedback: theoretical and pedagogical perspectives. In H. Nassaji, \& E. Kartchava (Eds.), Corrective Feedback in Second Language Teaching and Learning: Research, Theory, Applications, Implications (pp. ix-xv). New York: Routledge.

Oliver, R. (2000). Age differences in negotiation and feedback in classroom and pairwork. Language Learning, 50(1), 119-151.

Panova, I., \& Lyster R. (2002). Patterns of corrective feedback and uptake in an adult ESL classroom. TESOL Quarterly, 36(4), 573-595.

Park, E. S., Song, S., \& Shin, Y. K. (2015). To what extent do learners benefit from indirect written corrective feedback? A study targeting learners of different proficiency and heritage language status. Language Teaching Research, 20(6), 1-22. 
Seliger, H. W., \& Shohamy, E. (1989). Second language research methods: Oxford University Press.

Sheen, Y. (2004). Corrective feedback and learner uptake in communicative classrooms across instructional settings. Language Teaching Research, 8, 263-300. https://doi. org/10.1191/1362168804lr146oa

Sheen, Y. (2006). Exploring the relationship between characteristics of recasts and learner uptake. Language Teaching Research, 8(4), 361-392.

Sheen, Y. (2007). The effect of focused written corrective feedback and language aptitude on ESL learners' acquisition of articles. TESOL Quarterly, 41, 255-83. https://doi. org/10.1002/j.1545-7249.2007.tb00059.x

Suzuki, W., Nassaji, H., \& Sato, K. (2019). The effects of feedback explicitness and type of target structure on accuracy in revision and new pieces of writing. System, 81, 135-145.

Truscott, J. (1996). The case against grammar correction in L2 writing classes. Language Learning, 46, 327-369. https://doi.org/10.1111/j.1467-1770.1996.tb01238.x

Truscott, J. (1999). The case for grammar correction in L2 writing classes: A response to Ferris. Journal of Second Language Writing, 8, 111-122. https://doi.org/10.1016/S1060-3743 (99)80110-6

Truscott, J. (2001). Selecting errors for selective error correction. Concentric: Studies in Linguistics, 27(2), 93-108.

Truscott, J. (2004). Dialogue: Evidence and conjecture on the effects of correction: A response to Chandler. Journal of Second Language Writing, 13, 337-343. https://doi.org/10.1016/j. jslw.2004.05.002

Truscott, J. (2007). The effect of error correction on learners' ability to write accurately. Journal of Second Language Writing 16: 1-18. https://doi.org/10.1016/j.jslw.2007.06.003

Truscott, J., \& Hsu, A. Y. (2008). Error correction, revision, and learning. Journal of Second Language Writing, 17, 292-305.

Way, P., Joiner, E. G., \& Seaman, M. (2000). Writing in the secondary foreign language classroom: The effects of prompts and tasks on novice learners of French. The Modern Language Journal, 84(2), 171-184. doi:10.1111/modl.2000.84.issue-2 